UDC 316.43

LBC 60.9

\title{
THE PROBLEM OF QUALITY OF SERVICES IN THE NON-STATIONARY SOCIAL SERVICE INSTITUTION FOR THE ELDERLY IN BELGOROD REGION
}

\author{
Nataliya V. Lazurenko \\ Belgorod State National Research University, Belgorod, Russian Federation \\ Mariya S. Serkina \\ Belgorod State National Research University, Belgorod, Russian Federation
}

\begin{abstract}
Social service is of high quality provided that the purpose of the service is clearly defined, based on inclusiveness and focus on the client's personality, methodologically justified and provided on the basis of modern techniques and technologies. The authors conducted a sociological study aimed at identifying the problem of quality of services in a non-stationary institution for the elderly in one of the municipal districts of the Belgorod region. The respondents were consumers of services and specialists of the institution. Among the factors that reduce the availability of social services the following were found: leading-strings mentality of customers and the declarative principle of the service. The survey revealed that the services in the institution are provided taking into account individual and personal characteristics and the specific life situation of the elderly, have a clear purpose and assignment. Assessment of the quality of services provided was carried out in the following areas: by elderly customers, by specialists, by the administration of the institution. SWOT-analysis showed the most significant factors affecting the effective development of the institution on the basis of improving the quality of services for elderly citizens allowed to determine the list of problems that have a negative impact on the effective development of the institution. The express method of assessing the quality of services in a non-stationary institution in accordance with state standards is presented. It is concluded that the development of social services is taking into account the needs of elderly people based on improving the quality of social services. This, in turn, is reflected in the development and implementation of standardized evaluation methods and mechanisms.

Key words: social service, quality of services, non-stationary social service, the institution of non-stationary social service for elderly people, quality standard.
\end{abstract}

УДК 316.43

ББК 60.9

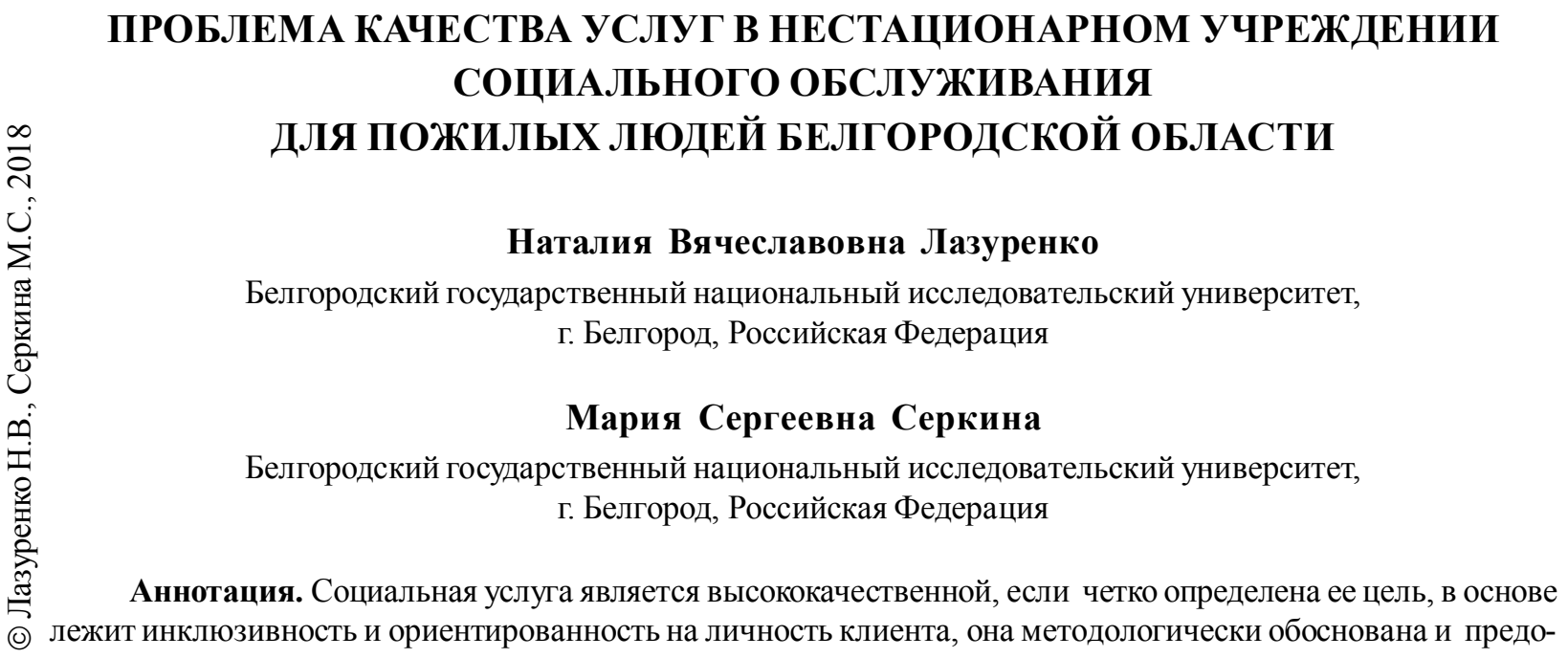


ставляется на основе современных методик и технологий. Авторами проведено социологическое исследование, направленное на выявление проблемы качества услуг в нестационарном учреждении для пожилых людей в одном из муниципальных районов Белгородской области. Респондентами выступали потребители услуг и специалисты учреждения. Среди факторов, снижающих доступность социальных услуг, обнаружены: иждивенческие настроения клиентов и заявительный принцип предоставления услуги. Анкетирование выявило, что услуги в учреждении предоставляются с учетом индивидуально-личностных особенностей и конкретной жизненной ситуации пожилых, имеют четкую цель и назначение. Оценка качества предоставляемых услуг производилась по направлениям: со стороны пожилых клиентов, со стороны специалистов, со стороны административного аппарата оранизации. SWOT-анализ показал наиболее значимые факторы, влияющие на эффективное развитие учреждения на основе улучшения качества услуг для пожилых граждан, и позволил определить перечень проблем, оказывающих на них негативное влияние. В статье представлена экспресс методика оценки качества услуг в нестационарном учреждении в соответствии с государственными стандартами. Сделаны выводы о том, что развитие системы социального обслуживания происходит с учетом потребностей пожилых людей, на основании повышения качества предоставляемых социальных услуг. Это выражается в разработке и внедрении унифицированных методов и механизмов оценки.

Ключевые слова: социальная услуга, качество услуг, нестационарное социальное обслуживание, учреждение нестационарного социального обслуживания для пожилых людей, стандарт качества.

\section{Введение}

На современном этапе актуализируются объективные вопросы расширения ассортимента предоставления услуг в системе социального обслуживания пожилых людей. Это происходит вследствие снижения уровня жизни достаточно большого пласта населения старших возрастных групп. Приоритетом становится повышение качества предоставляемых пожилым людям социальных услуг, которые должны определяться индивидуальными потребностями людей [5].

В соответствии с Федеральным законом РФ «Об основах социального обслуживания граждан в Российской Федерации» (от 28 декабря 2013 г. № 442-Ф3), социальная услуга действие или действия в сфере социального обслуживания по оказанию постоянной, периодической, разовой, в том числе и срочной, помощи, гражданину в целях улучшения условий его жизнедеятельности и (или) расширения его возможностей самостоятельно обеспечивать свои основные жизненные потребности [6].

Согласно государственному стандарту «качество социальной услуги» трактуется как «совокупность свойств социальной услуги, определяющая ее возможность и способность удовлетворить потребности клиента социальной службы и осуществить его социальную реабилитацию или социальную адаптацию» [1] .

Согласимся с российскими учеными и представим «качество услуги как соответствие идеального образа услуги, удовлетворяющего все стороны, и реального воплощения этой услуги. Идеальный образ качественной услуги подразумевает связанные между собой процесс, результат, сопоставимость цели и результата (результативность), достижение цели с наименьшими затратами (эффективность)» [8, с. 40].

Необходимо отметить, что в социальном обслуживании населения понятие «качество» услуги относится к сущности и результативности предоставленной услуги. Следовательно, при оценке качества услуг это могут быть качественные и количественные показатели.

По нашему мнению, социальная услуга может относится к «высококачественной» при соответствии следующим требованиям: четко определена цель, в основе лежит инклюзивность и ориентированность на адресность (личность клиента), предоставляется на основе современных методик и технологий, методологически обоснована.

В публикациях отечественных исследователей, как правило, выделяются три подхода к оценке качества услуги и эффективности ее предоставления. В частности, Л.В. Топчий выделяет следующие подходы [9]: первый подразумевает соотнесение норм качества социальных услуг с реальным проявлением результативности; второй предусматривает измерение эффективности при помощи показателей, позволяющих определить динамику преодоления социальных девиаций в обществе и проблем отдельных клиентов; третий предполагает внедрение критериев и показателей в практику социальной работы [9, с. 188]. 
По мнению Н.В. Фадеевой, наиболее распространенной концепцией оценки качества услуги является пятиступенчатая модель качества, или модель расхождения качества услуги, разработанная американскими учеными В. Зейтамль, А. Парасураманом и Л. Берри [11, с. 484].

Вторым по популярности методом оценки качества услуг, по мнению того же ученого, является метод «таинственного (тайного, скрытого) покупателя» [11, с. 486].

С.Д. Ильенковой, В.С. Мхитаряном и другими авторами описана модель оценки качества, получаемого потребителем обслуживания, которое базируется на концепции «нейтральной зоны», когда выделяются классификационные группы элементов обслуживания, различающиеся по характеру восприятия потребителем [10].

Учреждения социального обслуживания предоставляют услуги на основании государственных стандартов: ГОСТ Р 52495-2005 «Социальное обслуживание населения. Термины и определения», ГОСТ Р52496-2005 «Социальное обслуживание населения. Контроль качества социальных услуг. Основные положения», ГОСТ Р52497-2005 «Социальное обслуживание населения. Система качества учреждений социального обслуживания», ГОСТ Р 53058-2008 «Социальное обслуживание населения. Социальные услуги гражданам пожилого возраста» $[1 ; 2 ; 3 ; 4]$.

Обратимся к нормативно-правовой базе отдельного субъекта федерации в области стандартов качества социальных услуг. В данном ракурсе необходимо особо выделить Постановление Правительства Белгородской области «Об утверждении стандартов качества бюджетных услуг, на основании которого разработан Региональный стандарт «Качество услуг в области социальной защиты населения», действующий до принятия Ф3 № 442 [7].

В нормативно-правовых актах Белгородской области утвержден перечень основных требований к результатам работы бюджетных учреждений области и перечень индикаторов качества услуг в области социального обслуживания. Например, по критерию «услуга по предоставлению социального обслуживания в нестационарных учреждениях социального обслуживания» (обслуживание на дому) перечислены индикаторы и определен вес каждого в процентах.
Управлением социальной защиты Белгородской области разработаны методические рекомендации по внедрению отраслевой системы оплаты труда в нестационарных учреждениях, предусматривающие ответственность каждого сотрудника учреждения за свой участок работы. Указанным выше Постановлением правительства Белгородской области всем учреждениям было дано право на самостоятельное определение выплат стимулирующего характера. Как правило, выделяются основные надбавки, которые применяются учреждениями согласно Положению о выплате стимулирующих надбавок. К критериям для выделения дополнительных выплат относят: уровень образования, увеличение объема работ, выполнение дополнительных обязанностей, качество оказываемых услуг, сложность, напряженность и эффективность в работе.

\section{Методы исследования}

Для характеристики и подтверждения теоретических посылов нашей статьи приведем некоторые результаты социологического исследования «Изучение проблемы качества услуг в нестационарном учреждении для пожилых людей (на примере МБУСОССЗН «Комплексный центр социального обслуживания населения» Краснояружского района Белгородской области»), проведенного в январемарте 2018 г. сотрудниками кафедры социальной работы НИУ «БелГУ».

Цель исследования - выявить проблемы предоставления качественных услуг в нестационарном учреждении социального обслуживания для пожилых людей и определить отношение респондентов к существующей проблеме. Объектом изучения явились социальные услуги в системе социального обслуживания пожилых граждан; предметом - качество услуг, предоставляемых пожилым гражданам в комплексном центре социального обслуживания населения.

Первичная эмпирическая информация собиралась посредством анализа экономикостатистических материалов территориального органа Федеральной службы государственной статистики по Белгородской области, а также анализа документов МБУСОССЗН «Комплексный центр социального обслужива- 
ния населения» Краснояружского района Белгородской области; анкетного опроса работников органов социальной защиты населения: сотрудников Центра, УСЗН, администрации района $(n=78)$; анкетного опроса пожилых граждан, проживающих на территории муниципального района «Краснояружский район»получателей социальных услуг $(n=264)$.

При опросе пожильх граждан (получателей социальных услуг) использовались следующие методы исследования: анкетирование, методы сравнительного и структурнофункционального анализа.

Выборочная совокупность являлась квотной и целенаправленной. В качестве квотных критериев выбраны возраст и социальный статус, а типы вопросы анкеты - закрытые и полузакрытые (число ответов от 4 до 10). Применялась стандартизированная номинальная шкала. Обработка первичной информации производилась с помощью SPSS 22.0 v. Ошибка по репрезентирующим признакам не превышает 2,5\%.

В анкете выделено три блока вопросов, представляющих интерес для выявления качественно/некачественно предоставляемой услуги. В список не включались вопросы экспертного характера, которые могут потребовать специфической информации и квалификационной подготовки.

При опросе спещииалистов (сотрудники Центра, УСЗН, администрации района) использовались следующие методы: анкетирование, типологизация эмпирических данных, метод структурно-функционального анализа, составление сравнительных таблиц, комментирование первичных текстов.

Выборочная совокупность определялась посредством целенаправленной, квотной, гнездовой выборки. В качестве квотных критериев выборки применены признаки возраста, образования, стажа работы. Среди типов вопросов анкеты были выбраны закрытые, полузакрытые, открытые (с числом от 5 до 15). Использовалась стандартизированная номинальная шкала. Обработка первичной информации осуществлялась с помощью пакета прикладных программ SPSS 22.0 v. Ошибка по репрезентирующим признакам не превышает $2,5 \%$.

В анкете выделено пять блоков вопросов: факторы, снижающие доступность соци- альных услуг, проблемы в функционировании нестационарных учреждений для пожилых; кадровое обеспечение учреждений нестационарного обслуживания для пожилых и оценка профессиональной деятельности специалистов в данных учреждениях; информационное обеспечение работы учреждений и система контроля; соответствие предоставляемых услуг требованиям стандарта качества (вопросы анкеты составлены на основании критериев ГОСТ Р 53058-2008 «Социальное обслуживание населения»); оценка качества социального обслуживания в нестационарных учреждениях для пожилых и рекомендации по эффективности работы данных учреждений.

Некоторые вопросы анкеты для специалистов совпадали с вопросами для пожилых, что позволило получить сравнительную статистическую информацию о некоторых проблемах в вертикали: производители услуг потребители услуг. Кроме того, в список включались вопросы оценочного характера для получения более полной информации о проблеме качества предоставляемых услуг в нестационарных учреждениях социального обслуживания.

\section{Результаты исследования}

Численность охвата надомным социальным обслуживанием в районе составляет ежегодно от $7 \%$ до $9 \%$ пожилых граждан, проживающих на территории Краснояружского района.

Анкетирование выявило, что основными клиентами центра (надомное социальное обслуживание) являются пожилые люди и инвалиды в возрасте: старше 70 лет (85\%), 60-70 лет - $11 \%$, в возрасте 20-60 лет$4 \%$, младше 20 лет - менее $1 \%$. Большинство оценивает свое материальное положение как среднее (55\%).

На вопрос «Как Вы оцениваете социальное обслуживание в последнее время?» пожилые граждане ответили в основном положительно (80 \%). Однако свое беспокойство респонденты выразили в отношении культуры общения (5 \%), малого перечня бесплатных социальных услуг $(10 \%)$ и недостаточного количества лекарственных средств (15\%). По мнению респондентов, система социального 
обслуживания: может эффективно оказывать услуги пожилым (55\%); не способна на это (5\%); способна, но при условии увеличения финансирования и повышения зарплаты сотрудникам (40\%). По данным опроса для улучшения работы центра необходимо повысить заработную плату сотрудникам (25\%) и увеличить финансирование учреждения (40 \%).

Весьма важным для оценки качества оказываемых услуг являются взаимоотношения, складывающиеся между пожилыми людьми и специалистами. Отношением к себе сотрудников удовлетворены $90 \%$ респондентов; чаще всего претензии высказываются гражданами пенсионного возраста, находящимися на обслуживании не более 2-3 месяцев $11 \%$. Эти же $90 \%$ считают, что специалисты центра добросовестно выполняют свою работу, при этом: «полностью удовлетворены социальным работником» - 99 \%; «удовлетворены частично» - $1 \%$; «не удовлетворены» $0 \%$; «хотелось бы заменить социального работника» $-0 \%$.

По ответам на вопрос «Какие социальные услуги респонденты хотели бы получать дополнительно» нами выяснено, что большинство пожилых граждан удовлетворены набором социальных услуг и им не требуется дополнительных (71 \%). Однако некоторые (от 0,5 до 7 \%) предложили ввести следующие дополнительные услуги: пожелание круглосуточного нахождения социального работника с клиентом, стирка белья, приготовление пищи, доставка газет, общение с социальным работником, помывка в бане, ремонт хозяйственных построек, обеспечение топливом, обработка огорода, ремонт в доме, сопровождение в санаторий, поездка на службу в церковь, доставка в поликлинику, получение услуг специалиста-печника, уборка снега в зимний период, помощь в заготовке и консервировании овощей и фруктов, вынос мусора, предоставление бесплатного транспорта для поездки к врачу, парикмахерские услуги 1 раз в месяц, содействие в переписке, доставка воды и дров в баню, топка бани, замена лампочек, батареек, штор, укладка дров, прогулки с социальным работником, услуги няни-сиделки. Большая часть ответов (от $13 \%$ до $82 \%$ в разных подгруппах) - утверждение, что оказываемая помощь эффективна.

Изучив данные, полученные при ответе на вопрос «Есть ли среди перечисленных проблемы, которые волнуют Вас больше всего?», можно сделать следующие выводы. Самой «волнующей проблемой» является ухудшение здоровья, она получила почти половину всех голосов респондентов, а именно - $49 \%$ от общего числа опрошенных (мужчин $-13 \%$, женщин - $36 \%$ ). Очевидно, что это связанно с постоянно ухудшающимся с возрастом здоровьем. Примерно равное количество ответов набрали социально-психологические (18 \%), социально-бытовые проблемы (16\%), причем это больше волнует женщин, чем мужчин. Ни один из опрошенных не ответил, что его данные проблемы не интересуют.

Проанализировав данные, полученные при ответе на вопрос «Есть ли среди перечисленных услуг те, в которых Вы нуждаетесь больше всего? Если “да", то какие?», можно сделать вывод, что респонденты в основном нуждаются в социально-медицинских услугах, поскольку больше половины всех опрошенных ответило именно так (58 \%). Во время опроса некоторые ссылались на ухудшающееся качество «нашей медицины», отсутствие некоторых лекарственных препаратов и зачастую безразличное отношение врачей и общества к этому. Социально-бытовое обслуживание, организацию досуга и самореализацию отметили примерно равное количество опрошенных. Причем в организации досуга в основном нуждаются женщины. Лишь $2 \%$ опрошенных необходимо оказание психологической помощи, и среди них нет ни одного мужчины (табл. 1).

Таблиияа 1

Распределение ответов на вопрос «Есть ли среди перечисленных услуг те, в которых Вы нуждаетесь больше всего? Если “да”, то какие?»

\begin{tabular}{|c|c|c|c|c|}
\hline \multicolumn{5}{|c|}{ Варианты ответов (в \%) } \\
\hline Очень нуждаюсь & Нуждаюсь & Скорее да & Скорее нет & Не нуждаюсь \\
\hline $\begin{array}{c}\text { Социально-бытовое } \\
\text { обслуживание }\end{array}$ & В психологических & В медицинских & $\begin{array}{c}\text { В организации досу- } \\
\text { га и саморазвития }\end{array}$ & $\begin{array}{c}\text { Нет, это меня не } \\
\text { волнует }\end{array}$ \\
\hline $17 \%$ & $2 \%$ & $69 \%$ & $12 \%$ & $0 \%$ \\
\hline
\end{tabular}


По анализу данных, полученных при ответе на вопрос «Нуждаетесь ли Вы в какойлибо помощи? Если “да", то какой?», можно сделать следующие выводы: больше половины респондентов указали «материальная помощь» (68 \%), причем подавляющее большинство из них были женщины (62\%). Около $18 \%$ опрошенных нуждаются в какай-либо помощи только во время болезни, а $12 \%$ - только в помощи по дому. Интересен тот факт, что в основном в этих двух видах услуг нуждаются мужчины, причем их голоса распределились поровну $-8 \%$ и $8 \%$. В психотерапевтической помощи нуждается $22 \%$ респондентов, среди которых только женщины.

Отвечая на вопрос «Считаете ли Вы, что в учреждении достаточно внимания уделяется проблемам пожилых людей со стороны администрации?», большинство респондентов отмечает, что администрация достаточно делает для их блага (51\%).

Анкетирование выявило, что «услуги предоставляются с учетом индивидуальноличностных особенностей и конкретной жизненной ситуации» пожилых $(79,3 \%)$ и имеют «четкое, направленное назначение» $(75,9 \%)$.

В $75,1 \%$ случаев респонденты уверены в высокой квалификации персонала Центра. Большинство клиентов убеждены, что оценка качества услуг является проблемой $(57,2 \%)$. О критериях и показателях оценки качества социальных услуг пожилые люди в подавляющем большинстве своем не имеют представления (94\%). 74 \% получателей услуг высказались за изменение подходов к оценке качества, а 57 \% считают, что необходимо учитывать отзывы (мнение) получателей услуг. Большая часть респондентов $51 \%$ - выступает за личное участие в оценке качества услуг.

Опрос специалистов. Большинство опрошенных специалистов имеют высшее и неоконченное высшее образование (82 \%), у остальных - среднее специальное. Средний возраст опрошенных - 38 лет, средний стаж - 7 лет.

К факторам, снижающим доступность услуг, относятся «иждивенческие настроения клиентов» $(58,3 \%)$ и «низкая обеспеченность транспортом» (32,2\%). Транспортный вопрос возникает прежде всего в отдаленных сельских поселениях. Вопросы с иждевенческими настроеними появляются из-за недостаточного количества высококвалифицированных кадров $(16,8 \%)$.

Значительная часть выборки $(25,9 \%)$ указала на такой фактор, как «заявительный принцип», что, по нашему мнению, соответствует нормативно-правовому базису социальной защиты в РФ. Однако при таком подходе крайне трудно определить всю совокупность нуждающихся в социальных услугах, а это, в свою очередь, может отразиться на эффективности помощи (в исследовании около 85 \% получателей услуг считают их эффективными).

По мнению специалистов, в первую очередь к проблемам, которые волнуют пожилых людей, относятся следующие: питание $(66,7 \%)$, отношение обслуживающего персонала к клиентам (50\%), медицинское обслуживание $(33,3 \%)$, жилищные условия и социально-психологическая поддержка (по 16,7 \%). Причинами, по которым чаще всего пожилые граждане обращаются в Центр считаются: невозможность самообслуживания $(83,3 \%)$, отсутствие родственников (50 \%), невозможность проживания с родственниками (16,7\%).

Отдельный блок вопросов анкеты касается проблем в функиионировании нестационарных учреждений для пожилых. По мнению специалистов, наибольшее беспокойство в сфере социального обслуживания сегодня вызывают: платные услуги, отношение персонала к получателям услуг, малый перечень бесплатных социальных услуг (по 33,3 \%), отсутствие (недостаток) информации (по $16,7 \%)$. В то же время к проблемам, присущим нестационарным учреждениям для пожилых, людей относят: заработную плату сотрудников (83,3\%), финансирование учреждения (52\%), непрофессионализм работников учреждения, неукомплектованность кадрами, отсутствие уважительного отношения к клиентам (по $15 \%$ ). Что касается проблем в работе с пожилыми в нестационарном учреждении, то ответы распределились следующим образом: материальные - 83,3 \%, психологические - 66,7 \%, слабое финансирование $33,3 \%$, отсутствие качественных досуговых услуг - 16,7 \%.

Второй блок вопросов связан с кадровым обеспечением учреждений нестационар- 
ного обслуживания для пожилых и оценкой профессиональной деятельности специалистов в данных учреждениях. Респонденты оценивали работу персонала учреждений по 10-балльной шкале: 67 \% оценивают работу персонала высоко (от 6 до 8), культуру общения оценивают средне - $50 \%$ опрошенных поставили от 6 до 9 баллов, 33 \% анкетированных считают, что учреждения нестационарного обслуживания для пожилых не располагают необходимым числом специалистов.

Смена кадров, по мнению специалистов, происходит довольно часто, и связано это прежде всего с невысокой оплатой труда $(83,3 \%)$, психологическими перегрузками у сотрудников (50 \%) и непрофессионализмом $(7,7 \%)$. Факторами, влияющими на качество работы персонала в нестационарных учреждениях для пожилых людей, являются следующие: социальные - 83,3 \%, юридические (правовые) и физические - по 33,3 \%, психологические (высокое психоэмоциональное напряжение) и административно-управленческие (отсутствие единых требований, несвоевременное получение информации и др.) по $16,7 \%$.

Третий блок вопросов касался информаиионного обеспечения работы учреждений и системы контроля. По мнению экспертов, нормативно-правовая база в части критериев оценки качества услуг в нестационарных учреждениях для пожилых недостаточно разработана (90\% ответов).

Респондентам задавался вопрос «Достаточна ли информированность клиентов об услугах, предоставляемых учреждением нестационарного обслуживания?». Из анализа ответов следует, что информированность является недостаточной. Что касается внутренней системы контроля, то она, по мнению специалистов, недостаточна (67 \% ответов). Они считают, что для эффективной работы системы необходима возможность анонимно высказывать свои пожелания по улучшению качества услуг. Внешний контроль, по мнению респондентов, наиболее полно осуществляют органы социальной защиты населения.

Четвертый блок вопросов связан с $\mathrm{co}$ ответствием предоставляемых услуг требованиям стандарта качества. Вопросы анкеты составлены на основании критериев ГОСТ Р 53058-2008 [4]. В анкете перечислены виды социальных услуг и по каждой позиции («полностью соответствует», «частично соответствует», «не соответствует») пожилыми респондентами давался ответ.

При ответах на вопрос «Соответствуют ли требованиям стандарта качества социально-бытовые услуги?» наибольшее соответствие выявлено по позициям «сопровождение в медицинские учреждения» (48 \%), «покупка и доставка на дом продуктов» (частично соответствует - $67 \%$ ). Несоответствия чаще всего отмечены в строках «содействие в посещении учреждений культуры» (80\%), что может быть связано с проживанием большинства клиентов в сельской местности, а, соответственно, при недостаточно развитой инфраструктуре наблюдается рассредоточение проживания по территории района.

В ответах на вопрос анкеты «Соответствуют ли требованиям стандарта качества социально-медицинские услуги?» наибольшее соответствие выявлено в пунктах «поддержание условий проживания в соответствии с требованиями гигиены» (полностью соответствует - $50 \%$ и и «содействие в проведении медико-социальной экспертизы (полностью соответствует - 70 \%), а полное несоответствие - «оказание помощи в освоении и выполнении посильных физических упражнений» $(50 \%)$.

В ответах на вопрос анкеты «Соответствуют ли требованиям стандарта качества социально-экономические услуги?» наибольшее соответствие выявлено в пунктах «оказание материальной помощи» (полностью соответствует - 33 \%) и «консультирование» (частично соответствует - $68 \%$ ).

При распределении ответов респондентов на вопрос «Соответствуют ли требованиям стандарта качества социально-психологические услуги?» наибольшее совпадение наблюдается по позициям «консультирование» и «экстренная помощь» (по 33 \%), частичное совпадение по позиции «психологическая помощь» $(67 \%)$ и полное несоответствие наблюдается по позиции «социально-психологический патронаж» (в $50 \%$ случаев).

Среди ответов на вопрос «Соответствуют ли требованиям стандарта качества со- 
циально-правовые услуги?» выявлено полное соответствие по позиции «правовое консультирование» $(50 \%)$, частичное по позиции «оказание помощи в пенсионном обеспечении и предоставлении других социальных выплат» (67\%).

Пятый блок вопросов касается оценки качества сочиильного обслуживания в нестационарных учреждениях для пожилых и рекомендаций по повыщению эффективности работы данных учреждений. По мнению респондентов, сегодня в системе социального обслуживания эффективно оказываются услуги пожилым (67\%), лишь при условии расширения спектра оказываемых услуг (17\%). Качество социального обслуживания в данных учреждениях оценивают как среднее (в $50 \%$ случаев).

Специалистам задавался вопрос «Насколько часто поступают жалобы от клиентов нестационарных учреждений руководству?», при ответе $15 \%$ затрудняются ответить, $85 \%$ считают, что жалобы поступают очень редко.

На эффективность работы влияют следующие факторы: географическая отдаленность проживания клиентов (28 \%), психологические нагрузки (45\%), недостаточность транспортного сообщения (13\%).

Один из разделов анкеты рассматривает отношения социальных работников с клиентами. Нами выяснено, что отношения между клиентами и социальными работниками складываются доброжелательные (в 95 \% случаев), однако конфликтные ситуации иногда возникают.
Причину повышения требований к специалистам респонденты видят в «увеличении числа желающих работать в системе социального обслуживания» $(1,2 \%)$ и «повышении качества предоставляемых услуг» $(81,8 \%)$. Очевидно, что при повышении требования к специалистам, повышается и качество предоставляемых услуг населению.

Приоритеты развития учреждения нами определены при помощи соответствующей таблицы оценок. Проблемы оцениваются по 10-балльной шкале (табл. 2)

Для решения проблем эффективности разâèòèÿ ó־đåmäåí èÿ í ài è ñî ñòàâëåí SWOT-aHaлиз деятельности МБУСОССЗН «Комплексный центр социального обслуживания населения» Краснояружского района.

Цель - повышение доступности и качества социальных услуг. SWOT-анализ направлен на выявление: преимуществ (сильных сторон), способствующих эффективной деятельности учреждения на основе улучшения качества услуг пожилым гражданам; недостатков (слабых сторон), сдерживающих и негативно влияющих на эффективное развитие учреждения; возможностей, оказывающих положительное влияние на эффективность деятельности учреждения на основе улучшения качества услуг пожилым гражданам; угроз, оказывающих негативное влияние на эффективное развитие учреждения.

SWOT-анализ, представленный в таблице 3, показывает наиболее значимые факторы, влияющие на эффективное развитие учреждения на основе улучшения качества услуг пожилым гражданам. На основании

Таблица 2

Оценка проблем специалистами

\begin{tabular}{|c|c|c|c|c|}
\hline $\begin{array}{l}\text { № } \\
\Pi / \Pi\end{array}$ & Наименование проблемы & $\begin{array}{l}\text { Важность } \\
\text { проблемы }\end{array}$ & $\begin{array}{c}\text { Неотложность } \\
\text { проблемы }\end{array}$ & $\begin{array}{c}\text { Тенденция } \\
\text { развития }\end{array}$ \\
\hline 1 & Слабое аналитическое и информационное обеспечение & 7 & 6 & $?$ \\
\hline 2 & $\begin{array}{l}\text { Мониторинг изучения целевых групп, нуждающихся в соци- } \\
\text { альной помощи }\end{array}$ & 10 & 8 & $?$ \\
\hline 3 & Отсутствие маркетинговых исследований & 8 & 9 & $?$ \\
\hline 4 & Недостаток специальных знаний & 6 & 8 & $?$ \\
\hline 6 & Субъективное, одностороннее представление фактов & 4 & 4 & $?$ \\
\hline 7 & Недостаточное количество опыта работы в данной сфере & 7 & 9 & $?$ \\
\hline 8 & Разочарование потребителей услуг, имидж организации & 6 & 5 & $?$ \\
\hline 9 & Мониторинг оценки эффективности деятельности учреждения & 10 & 8 & $?$ \\
\hline
\end{tabular}




\section{Матрица SWOT-анализа деятельности МБУСОССЗН «Комплексный центр} социального обслуживания населения» Краснояружского района

\begin{tabular}{|c|c|}
\hline Сильные стороны & Слабые стороны \\
\hline $\begin{array}{l}\text { 1. Высокопрофессиональный, мотивированный, кол- } \\
\text { лектив. Практическое отсутсвие текучки кадров. } \\
\text { 2. Популярность центра в районе. } \\
\text { 3. Наличие инновационных социальных методик и тех- } \\
\text { нологий. } \\
\text { 4. Проведение мониторингов по выявлению нуждаемо- } \\
\text { сти клиентов, адресный подход. } \\
\text { 5. Широкий спектр бесплатных услуг. } \\
\text { 6. Межведомственное взаимодействие. } \\
\text { 7. Своевременное формирование заявок на финансиро- } \\
\text { вание. } \\
\text { 8. Долгосрочные целевые программы в Белгородской } \\
\text { области. } \\
\text { 9. Информационная политика учреждения. }\end{array}$ & $\begin{array}{l}\text { 1. Иждивенческие настроения (непринятие платных ус- } \\
\text { луг). } \\
\text { 2. Возможность возникновения конфликтных ситуаций } \\
\text { (особая категория - пожилые). } \\
\text { 3. Низкая платежеспособность (невозможность оплаты } \\
\text { платных услуг). } \\
\text { 4. Невысокая заработная плата специалистов. Не доста- } \\
\text { точность финансирования. } \\
\text { 5. Неразвитость специализированных услуг для отдель- } \\
\text { ных категорий (например, инвалидов с определенными } \\
\text { заболеваниями). } \\
\text { 6. Отсутствие услуг по социально-трудовой и профес- } \\
\text { сиональной реабилитации (особенно для определенных } \\
\text { категорий). } \\
\text { 7. Профессиональное выгорание специалистов. } \\
\text { 8. Мониторинг востребованности социальных услуг. }\end{array}$ \\
\hline Возм & Угрозы \\
\hline $\begin{array}{l}\text { 1. Новая и дополненная нормативная база. } \\
\text { 2. Повышение оплаты труда специалистов. } \\
\text { 3. Расширение перечня дополнительных платных услуг. } \\
\text { 4. Реализация целевых программ различных уровней. } \\
\text { 5. Повышение средней заработной платы социальных } \\
\text { работников, оказывающих социальные услуги в системе } \\
\text { социальной защиты - до } 100 \text { \% от средней заработной } \\
\text { платы по субъекту. }\end{array}$ & $\begin{array}{l}\text { 1. Отсутствие достаточного финансирования. } \\
\text { 2. Старение населения и вследствие этого увеличение } \\
\text { количества пожилых граждан. } \\
\text { 3. Низкая социальная ответственность и иждивенческое } \\
\text { настроение населения. } \\
\text { 4. Невысокий уровень доходов населения. } \\
\text { 5. Правовая безграмотность населения. } \\
\text { 6. Удаленность помещения центра. } \\
\text { 7. Несоответствие материально-технической базы тре- } \\
\text { бованиям и запросам клиентов. }\end{array}$ \\
\hline
\end{tabular}

SWOT-анализа определен перечень проблем, оказывающих негативное влияние на эффективное развитие учреждения.

В качестве выводов представляем «экспресс методику оценки качества услуг в нестационарном учреждении» (МБУСОССЗН «Комплексный центр социального обслуживания населения» Краснояружского района) в соответствии с государственными стандартами. Индикаторы качества услуг представлены в таблице 4.

А - наличие/отсутствие критерия в МБУСОССЗН «Комплексный центр социального обслуживания населения» Краснояружского района. Б - индикатор (в баллах) в МБУСОССЗН «Комплексный центр социального обслуживания населения» Краснояружского района. В - индикатор по номенклатурной шкале (всего 100 баллов).

Качество услуг оценивается по шкале в 100 баллов, где низкий уровень - от 0 баллов до 50 баллов, средний - от 51 балла до 80 баллов, высокий - от 80 баллов до 100 баллов (см. табл. 4).

Таким образом, для МБУСОССЗН «Комплексный центр социального обслужи- вания населения» Краснояружского района характерным является: в области нормативно-правового обеспечения - высокий уровень качества услуг (80 баллов); в области кадрового обеспечения - высокий уровень (85 баллов); в области информационного обеспечения - средний уровень (70 баллов); в области социально-правовых услуг - средний уровень (65 баллов); в области социально-бытовых услуг - высокий уровень (80 баллов); в области социально-психологических услуг - низкий уровень (13 баллов); в области социально-экономических услуг средний уровень (65 баллов).

\section{Выводы}

Развитие системы социального обслуживания происходит с учетом потребностей пожилых людей и на основании улучшения качества предоставляемых социальных услуг. Это выражается в разработке и внедрении унифицированных методов и механизмов оценки со стороны пожилых клиентов, специалистов и администрации. 


\section{Индикаторы качества услуг в МБУСОССЗН «Комплексный центр социального обслуживания населения» Краснояружского района}

\begin{tabular}{|c|c|c|c|c|c|}
\hline \multirow{2}{*}{$\begin{array}{l}\text { № } \\
\Pi / \Pi \\
\end{array}$} & \multirow{2}{*}{ Показатель } & \multirow{2}{*}{ Критерий } & \multicolumn{3}{|c|}{ Индикатор } \\
\hline & & & $\mathrm{A}$ & 5 & $\mathrm{~B}$ \\
\hline 1 & $\begin{array}{l}\text { Нормативно- } \\
\text { правовое } \\
\text { обеспечение }\end{array}$ & $\begin{array}{l}\text { 1.1. Концепция развития Учреждения. } \\
\text { 1.2. Документы разных уровней, касающиеся качества услуг: } \\
\text { - федеральные; } \\
\text { - региональные; } \\
\text { - местные; } \\
\text { - уровня учреждения. } \\
\text { 1.3. Наличие индикаторов качества услуг. }\end{array}$ & $\begin{array}{l}- \\
+ \\
+ \\
- \\
- \\
+\end{array}$ & $\begin{array}{l}- \\
15 \\
15 \\
- \\
30 \\
20 \\
80\end{array}$ & $\begin{array}{l}30 \\
15 \\
15 \\
10 \\
30 \\
20 \\
100\end{array}$ \\
\hline 2 & $\begin{array}{l}\text { Кадровое } \\
\text { обеспечение }\end{array}$ & $\begin{array}{l}\text { 2.1. Укомплектованность учреждения специалистами (текучесть кадров). } \\
\text { 2.2. Наличие необходимого образования, квалификации, профессио- } \\
\text { нальной подготовки. } \\
2.3 \text { Опыт работы. } \\
\text { 2.4. Наличие должностных инструкций. } \\
\text { 2.5. Высокие морально-этические качества, чувство ответственности. }\end{array}$ & $\begin{array}{l}- \\
+- \\
+ \\
+ \\
+\end{array}$ & $\begin{array}{l}- \\
10 \\
25 \\
20 \\
30 \\
85\end{array}$ & $\begin{array}{l}30 \\
25 \\
25 \\
20 \\
30 \\
100\end{array}$ \\
\hline 3 & $\begin{array}{l}\text { Информаци- } \\
\text { онное и мето- } \\
\text { дическое } \\
\text { обеспечение }\end{array}$ & $\begin{array}{l}\text { 3.1. Соответствие стандарта с требованиями, которым должны соот- } \\
\text { ветствовать услуги. } \\
\text { 3.2. Информация об учреждении, регламент предоставления услуг. } \\
\text { 3.3. Состояние информации соответствует правилам закона РФ } \\
\text { «О защите прав потребителей». } \\
\text { 3.4. Получение оценки качества услуги со стороны ее получателя. } \\
\text { 3.5. Разработка текущих перспективных планов работы. } \\
\text { 3.6. Разработка критериев оценки деятельности учреждения и работ- } \\
\text { ников. } \\
\text { 3.7. Гарантийные обязательства учреждения - исполнителя услуг. }\end{array}$ & $\begin{array}{l}+ \\
+- \\
+- \\
+- \\
+- \\
+- \\
+\end{array}$ & $\begin{array}{c}10 \\
10 \\
10 \\
10 \\
5 \\
15 \\
10 \\
70 \\
\end{array}$ & $\begin{array}{c}20 \\
10 \\
\\
10 \\
20 \\
10 \\
\\
30 \\
1 \\
0 \\
100 \\
\end{array}$ \\
\hline 4 & $\begin{array}{l}\text { Социально- } \\
\text { правовые ус- } \\
\text { луги }\end{array}$ & $\begin{array}{l}\text { 4.1. Оказание помощи в оформлении обязательного медицинского } \\
\text { страхования. } \\
\text { 4.2. Оказание содействия в получении клиентами юридической по- } \\
\text { мощи. } \\
\text { 4.3. Помощь в оформлении документов. } \\
\text { 4.4. Содействие в получении бесплатной помощи адвоката. }\end{array}$ & $\begin{array}{l}+ \\
+ \\
+ \\
+-\end{array}$ & $\begin{array}{l}15 \\
20 \\
20 \\
10 \\
65\end{array}$ & $\begin{array}{l}20 \\
20 \\
20 \\
20 \\
100\end{array}$ \\
\hline 5 & $\begin{array}{l}\text { Социально- } \\
\text { бытовые ус- } \\
\text { луги }\end{array}$ & $\begin{array}{l}\text { 5.1. Предоставление мягкого инвентаря (одежда, обувь, постельные } \\
\text { принадлежности). } \\
\text { 5.2. Содействие в приготовлении пищи. } \\
\text { 5.3. Организация ритуальных услуг. } \\
\text { 5.4. Содействие в организации прохождения диспансеризации. } \\
\text { 5.5. Обеспечение досуга, участия в культурных мероприятий. } \\
\text { 5.6. Оказание помощи в отправке корреспонденции. }\end{array}$ & $\begin{array}{l}+- \\
+- \\
+- \\
+- \\
+ \\
+-\end{array}$ & $\begin{array}{c}4 \\
5 \\
8 \\
8 \\
10 \\
4 \\
80\end{array}$ & $\begin{array}{c}8 \\
10 \\
8 \\
8 \\
10 \\
8 \\
100\end{array}$ \\
\hline 6 & $\begin{array}{l}\text { Социально- } \\
\text { психологиче- } \\
\text { ские услуги }\end{array}$ & $\begin{array}{l}\text { 6.1. Консультирование. } \\
\text { 6.2. Психодиагностика. } \\
\text { 6.3. Психотерапия. } \\
\text { 6.4. Социально-психологический патронаж. } \\
\text { 6.5. Психотренинги. } \\
\text { 6.6. Клубы общения. } \\
\text { 6.7. Экстренная помощь. }\end{array}$ & $\begin{array}{l}- \\
- \\
+- \\
- \\
- \\
+- \\
-\end{array}$ & $\begin{array}{c}- \\
\\
- \\
8 \\
- \\
5 \\
13 \\
\end{array}$ & $\begin{array}{c}15 \\
15 \\
15 \\
15 \\
10 \\
15 \\
15 \\
100 \\
\end{array}$ \\
\hline 7 & $\begin{array}{l}\text { Социально- } \\
\text { экономиче- } \\
\text { ские услуги }\end{array}$ & $\begin{array}{l}\text { 7.1. Содействие в обеспечении нуждающихся клиентов технически- } \\
\text { ми средствами. } \\
\text { 7.2. Содействие в обеспечении одеждой, обувью (при выписке из } \\
\text { стационара). } \\
\text { 7.3. Содействие в получении льгот, пособий, компенсаций. }\end{array}$ & $\begin{array}{l}+ \\
+- \\
+-\end{array}$ & $\begin{array}{l}25 \\
15 \\
25 \\
65\end{array}$ & $\begin{array}{c}25 \\
\\
25 \\
50 \\
100 \\
\end{array}$ \\
\hline
\end{tabular}


Меры, необходимые для повышения эффективной деятельности нестационарного учреждения социального обслуживания для пожилых граждан: осуществление мониторинга оценки эффективности деятельности учреждения; создание и внедрение единой системы оценки качества предоставляемых услуг; доработка и внедрение единого программного обеспечения государственной системы социального обслуживания для формирования баз данных количественных и качественных показателей социального обслуживания; укомплектованность кадрами. В ряду критериев, по которым возможно оценить качество социальных услуг (соответственно и эффективность деятельности учреждения в целом), следует выделить: укрепление или поддержание физического и психического здоровья, оптимизация среды жизнедеятельности, оптимизация условий для реализации интеллектуально-культурных потребностей, укрепление социальной защищенности пожилых.

Нестационарное учреждение социального обслуживания в целом предоставляют социальные услуги гражданам пожилого возраста традиционно на высоком уровне в области нормативно-правового, социально-бытового, кадрового и информационного обеспечения, и на достаточно низком уровне производятся социально-психологические и социально-правовые услуги.

Социальная услуга является «высококачественной», если четко определена цель, в основе ее лежит инклюзивность и ориентированность на адресность, методологически обоснована и предоставляется на основе современных методик и технологий.

\section{СПИСОК ЛИТЕРАТУРЫ}

1. ГОСТ Р 52495-2005. Социальное обслуживание населения. Термины и определения. - Электрон. текстовые дан. - Режим доступа: http://docs. cntd.ru/document/1200043127.

2. ГОСТ Р52496-2005. Социальное обслуживание населения. Контроль качества социальных услуг. Основные положения. - Электрон. текстовые дан. - Режим доступа: http://docs.cntd.ru/document/ 1200043281.

3. ГОСТ Р52497-2005. Социальное обслуживание населения. Система качества учреждений социального обслуживания. - Электрон. текстовые дан. - Режим доступа: www.sirotstvo.ru/files/3106/ StandartTD.PDF.

4. ГОСТ Р 53058-2008. Социальное обслуживание населения. Социальные услуги гражданам пожилого возраста. - Электрон. текстовые дан. - Режим доступа: http://docs.cntd.ru/document/1200068704.

5. Натахина, В. В. Социальное обслуживание пожилых людей в условиях реформирования общества : дис... канд. социол. наук / Натахина Вера Викторовна. - Москва, 2009. - 185 с.

6. Об основах социального обслуживания граждан в Российской Федерации (ред. от 21.07.2014) : [принят 28 декабря 2013 г. № 442-Ф3]. Доступ из справ.-правовой системы «КонсультантПлюс».

7. Об утверждении стандартов качества бюджетных услуг : [постановление Правительства Белгородской области от 9 июня 2006 г. № 135-пп]. Режим доступа: http://yadonor.ru/archivdoc_21.htm.

8. Оценка эффективности деятельности учреждений социальной поддержки населения / П. В. Романов [и др.] ; под ред. П. В. Романова, Е. Р. ЯрскойСмирновой. - М. : Моск. обществ. науч. фонд; Центр социал. политики и гендерных исслед., 2007. -234 с. (Серия «Научные доклады: независимый экономический анализ»).

9. Топчий, Л. В. Социальное обслуживание населения: ценности, теория, практика: учеб.пособие для студентов вузов / Л. В. Топчий.- М. : Изд-во РГСУ, 2012. $-322 \mathrm{c}$.

10. Управление качеством : учеб. для вузов / С. Д. Ильенкова [и др.] ; под ред. С. Д. Ильенковой. - 2-е изд., перераб. и доп. - М. : Юнити-Дана, 2003. -334 c.

11. Фадеева, Н. В. Методология оценки качества услуг / Н. В. Фатеева // Вестник ТГТУ. - 2012. T. 18, № 2. - C. 484-492.

\section{REFERENCES}

1. GOST $R$ 52495-2005. Sotsialnoe obsluzhivanie naseleniya. Terminy i opredeleniya [GOST R 52495-2005. Social Service of the Population. Terms and Definitions]. URL: http://docs.cntd.ru/ document/gost-r-52495-2005.

2. GOST R52496-2005. Sotsialnoe obsluzhivanie naseleniya. Kontrol kachestva sotsialnykh uslug. Osnovnye polozheniya [GOST R52496-2005. Social Service of the Population. Quality Control of Social Services. General Provisions]. URL: http://docs.cntd.ru/document/1200043281.

3. GOST R52497-2005. Sotsialnoe obsluzhivanie naseleniya. Sistema kachestva uchrezhdeniy sotsialnogo obsluzhivaniya [GOST R52497-2005. Social Service of the Population. The 


\section{СОЦИОЛОГИЯ И СОЦИАЛЬНЫЕ ТЕХНОЛОГИИ}

System of Social Service Quality]. URL: http:// www.sirotstvo.ru/files/3106/StandartTD.PDF.

4. GOST $R$ 53058-2008. Sotsialnoe obsluzhivanie naseleniya. Sotsialnye uslugi grazhdanam pozhilogo vozrasta [GOST R 53058-2008. Social Service of the Population. Social Services for Elderly Citizens]. URL: http://docs.cntd.ru/document/ 1200068704.

5. Natakhina V.V. Sotsialnoe obsluzhivanie pozhilykh lyudey $v$ usloviyakh reformirovaniya obshchestva: dis... kand. sotsiol. nauk [Social Services for Elderly Citizens in the Conditions of Social Reforms. Cand. sociol. sci. diss]. Moscow, 2009. 185 p.

6. Ob osnovakh sotsialnogo obsluzhivaniya grazhdan $v$ Rossiyskoy Federatsii (red. ot 21.07.2014): prinyat 28 dekabrya 2013 g. № 442$F Z$ [Federal Law 'On the Basics of Social Services for Citizens in the Russian Federation' (ed. of 21 July 2014): Adopted on December 28, 2013. № 442FZ]. Access from reference legal system "KonsultantPlyus".

7. Ob utverzhdenii standartov kachestva byudzhetnykh uslug: postanovlenie Pravitelstva
Belgorodskoy oblasti ot 9 iyunya 2006 g. № 135-pp [Decree of the Government of the Belgorod Region 'On Approval of the Quality Standards of Budget Services' of June 9, 2006 No. 135-p]. URL: http:// yadonor.ru/archivdoc $21 . \mathrm{htm}$

8. Romanova P.V., Yarskaya-Smirnova E.R., eds. Otsenka effektivnosti deyatelnosti uchrezhdeniy sotsialnoy podderzhki naseleniya [Evaluation of the effectiveness of social support institutions]. Moscow, Moscow Public Science Foundation; Center for Social Policy and Gender Studies, 2007. $234 \mathrm{p}$.

9. Topchiy L.V. Sotsialnoe obsluzhivanie naseleniya: tsennosti, teoriya, praktika [Social Services for the Population: Values, Theory, Practice]. Moscow, Izd-vo RGSU, 2012. 322 p.

10. Ilyenkova S.D. Upravlenie kachestvom [Quality Control]. Moscow, Yuniti-Dana Publ., $2003.334 \mathrm{p}$.

11. Fadeeva N.V. Metodologiya otsenki kachestva uslug [Methodology for Assessing the Quality of Services]. Vestnik Tverskogo gosudarstvennogo teknicheskogo universiteta, 2012, vol. 18, no. 2, pp. 448-492.

\section{Information about the Authors}

Nataliya V. Lazurenko, Candidate of Sciences (Sociology), Associate Professor, Department of Social Work, Belgorod State National Research University, Preobrazhenskaya St., 78, 308009 Belgorod, Russian Federation, lazurenko@bsu.edu.ru.

Mariya S. Serkina, Postgraduate Student, Department of Social Work, Belgorod State National Research University, Preobrazhenskaya St., 78, 308009 Belgorod, Russian Federation, maxa3390@mail.ru.

\section{Информация об авторах}

Наталия Вячеславовна Лазуренко, кандидат социологических наук, доцент кафедры социальной работы, Белгородский государственный национальный исследовательский университет, ул. Преображенская, 78, 308009 г. Белгород, Российская Федерация, lazurenko@bsu.edu.ru.

Мария Сергеевна Серкина, аспирант кафедры социальной работы, Белгородский государственный национальный исследовательский университет, ул. Преображенская, 78, 308009 г. Белгород, Российская Федерация, таха3390@mail.ru. 